CZASOPISMO INŻYNIERII LADDOWEJ, ŚRODOWISKA I ARCHITEKTURY

JOURNAL OF CIVIL ENGINEERING, ENVIRONMENT AND ARCHITECTURE

JCEEA, t. XXXII, z. 62 (3/II/15), lipiec-wrzesień 2015, s. 221-242

Krzysztof KUCHTA ${ }^{1}$

Izabela TYLEK ${ }^{2}$

\title{
KRYTERIUM SZTYWNOŚCI W PROJEKTOWANIU POPRZECZNYCH ŻEBER BLACHOWNIC
}

\begin{abstract}
W artykule przedstawiono podstawowe metody wymiarowania pośrednich poprzecznych żeber blachownic ze względu na kryterium sztywności giętnej i podłużnej. Zakres opracowania obejmuje opis koncepcji i metod wyznaczania optymalnej względnej sztywności giętnej pośrednich żeber poprzecznych blachownic na podstawie liniowej i nieliniowej teorii stateczności płyt użebrowanych. Przedstawiono również propozycje wymiarowania pośrednich poprzecznych żeber blachownic w stanie nadkrytycznym oparte na dodatkowym kryterium sztywności podłużnej żebra. Porównano również wymagania, jakie stawiane są sztywności giętnej żeber w wybranych normach projektowania konstrukcji stalowych zestawiając je $\mathrm{z}$ formułami teoretycznymi i empirycznymi.
\end{abstract}

Słowa kluczowe: użebrowanie, żebra poprzeczne, żebra pośrednie, Eurokod 3, stateczność płyt użebrowanych

\section{Wprowadzenie}

Optymalne, z punktu widzenia minimalizacji masy profilu, kształtowanie dwuteowych blachownic stalowych, w których dominującym czynnikiem wytężenia przekroju jest moment zginający, wymaga stosowania środników o dużych smukłościach. Zbyt duża smukłość środnika powoduje jednak stosunkowo wczesne pojawianie się efektów niestateczności lokalnej oraz ich sprzężeń z efektami niestateczności ogólnej. Ekonomicznie efektywnym sposobem przeciwdziałania temu niekorzystnemu zjawisku jest zastosowanie poprzecznego lub podłużnego użebrowania albo fałdowe wyprofilowanie środnika. W praktyce inżynierskiej stosuje się jedynie profilowania fałdowe o tworzącej prostopadłej do osi środnika - fałda najczęściej ukształtowana jest w postaci sinusoidy lub trapezu. Odpowiedni dobór parametrów geometrycznych fałd umożliwia

\footnotetext{
${ }^{1}$ Autor do korespondencji: Krzysztof Kuchta, Politechnika Krakowska, 31-155 Kraków, ul. Warszawska24,kkuchta@pk.edu.pl

${ }^{2}$ Izabela Tylek, Politechnika Krakowska, 31-155 Kraków, ul. Warszawska 24, itylek@pk.edu.pl
} 
osiągnięcie na tyle dużej sztywności giętnej (w płaszczyźnie prostopadłej do osi dźwigara) i postaciowej (w płaszczyźnie dźwigara), że utrata stateczności środnika nie nastapi przed osiagnięciem przez naprężenia granicy plastyczności materiału. Mankamentem tej metody jest, uzasadniona ekonomicznie, konieczność stosowania technologicznie zaawansowanych linii automatycznego spawania fałdowych środników do pasów oraz ograniczenie grubości środników ze względu na uwarunkowania technologiczne gięcia blach na zimno. $\mathrm{Z}$ tego względu w stalowym budownictwie kubaturowym preferowane sa środniki z fałdami sinusoidalnymi o grubościach nie przekraczających $6,0 \mathrm{~mm}$. Ograniczenia tego nie ma pierwsza z wyżej wymienionych metod. Należy jednak zaznaczyć, że mimo ciągłego postępu w dziedzinie automatyzacji procesów spawalniczych użebrowanie belki blachownicowej nadal jest jeszcze wykonywane ręcznie, co w istotnym stopniu zwiększa koszty jej wytwarzania.

W połowie XIX w. podczas budowy pierwszych stalowych skrzynkowych mostów kolejowych - Conway (1848) i Britannia (1850), szkocki inżynier W. Fairbairn świadomie, w efekcie badań wielu prototypów, zastosował użebrowanie pionowych ścian skrzynki jako zabezpieczenie przedwczesnego ich wyboczenia [28]. Wspomniane powyżej mosty zostały zaprojektowane i oddane do użytkowania ponad 40 lat przed opublikowaniem przez G. H. Bryana (1891) rozwiązania zagadnienia stateczności ściskanej płyty wolnopodpartej, które uważa się za kamień węgielny teorii stateczności sprężystej konstrukcji cienkościennych. Obydwa mosty, Conway - jednoprzę̧łowy o rozpiętości $122 \mathrm{~m}$ i Britannia - czteroprzęsłowy o rozpiętości głównych przęseł $140 \mathrm{~m}$, funkcjonują do dnia dzisiejszego.

Podczas badań modelowych pierwszych mostów blachownicowych zauważono, że zastosowanie żeber usztywniających powoduje zwiększenie wartości normalnych i stycznych naprężeń krytycznych wyboczenia sprężystego środnika oraz krytycznych naprężeń normalnych pasów. Okazało się, że powyższa metoda zwiększania nośności blachownic jest znacznie ekonomiczniejsza od zwiększania grubości płyt środnika i pasów. Przez okres ponad 100 lat krytyczne naprężenia wyboczenia sprężystego użebrowanych płyt środnika i pasów stanowiły podstawę wymiarowania blachownic, mimo iż już w 1886 r. J.M. Wilson opisał mechanizm pracy nadkrytycznej blachownic mostów kolejowych [10]. Uważano, że podstawowym kryterium wymiarowania jest sztywność giętna żebra, ponieważ żebra powinno być na tyle sztywne, aby linie węzłowe wyboczonej powierzchni środnika uformowały się w ich osiach. Wymiarowanie żeber przeprowadzano korzystając z oszacowań empirycznych oraz teorii stateczności sprężystej płyt użebrowanych.

Wprowadzenie do praktyki inżynierskiej zasad projektowania umożliwiających wykorzystanie nadkrytycznej rezerwy nośności zmieniło sposób wymiarowania żeber poprzecznych blachownic. W ramach nowych procedur wymiarowania kryteria sztywności żebra nie zostały jednak usunięte lub zastąpione nowymi formułami, lecz zostały uzupełnione o formuły stanu granicznego nośności. 


\section{Ksztaltowanie przekroju żeber poprzecznych}

Powszechnie stosowanym $\mathrm{w}$ obliczeniach inżynierskich modelem statycznym żebra poprzecznego blachownicy jest fikcyjny, wyizolowany z konstrukcji blachownicy, pręt dwuprzegubowo podparty o rozpiętości równej wysokości płyty środnika. W najbardziej ogólnym przypadku obciążeniowym jest on prętem ściskanym i dwukierunkowo zginanym; przy czym żebra pośrednie, w przeciwieństwie do skrajnych żeber podporowych, najczęściej są zginane jedynie w płaszczyźnie prostopadłej do powierzchni środkowej środnika. Przyjęcie modelu prętowego wymaga zdefiniowania pola przekroju pręta zastępczego. Przekrój pręta zastępczego tworzą kształtowniki żeber oraz przyległa część płyty środnika $l_{w, e f f}$ o różnie, arbitralnie definiowanej szerokości (tabl. 1). Należy podkreślić, że dodanie do przekroju zastępczego przyległej części środnika jedynie częściowo uwzględnienia współpracę kształtowników żebra z płytą środnika. We wspomnianym modelu statycznym zazwyczaj całkowicie pomija się oddziaływania sprężystych więzi kinematycznych tworzonych przez płytę środnika.

Tablica 1. Szerokość przyległej płyty środnika $l_{w, e f f}$ zastępczego przekroju żebra

Table 1. Adjacent web plate width $l_{w, \text { eff }}$ of substitute stiffener cross-section

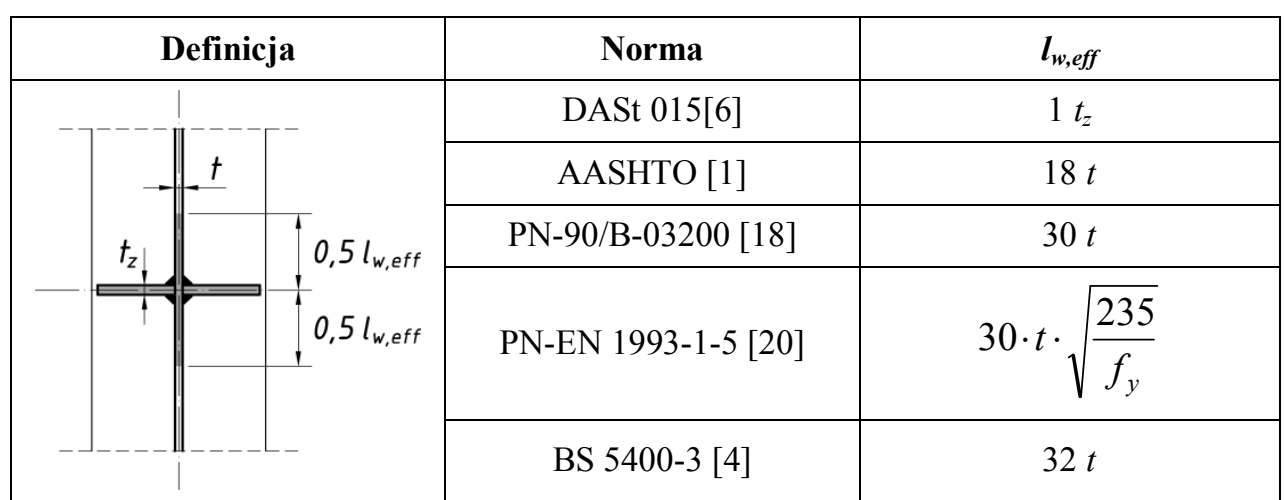

$t_{z}-$ grubość przyległej do środnika ścianki żebra, $f_{y}$ - granica plastyczności stali środnika

Najczęściej żebra pośrednie projektowane są z kształtowników o przekroju otwartym: płaskowników, kątowników i teowników, które stosowane są zarówno w układzie żebra podwójnego (parzystego) jak i pojedynczego (nieparzystego), co pokazano na rys. 1 . 
a)
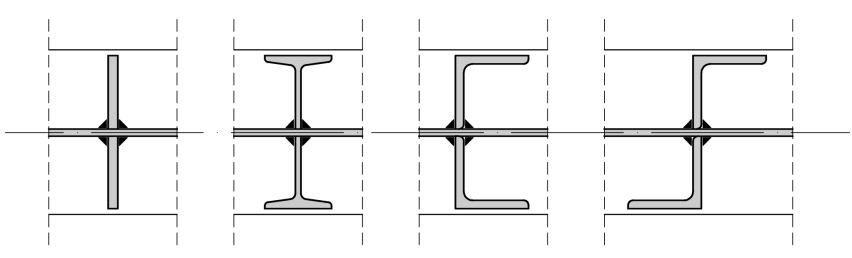

b)

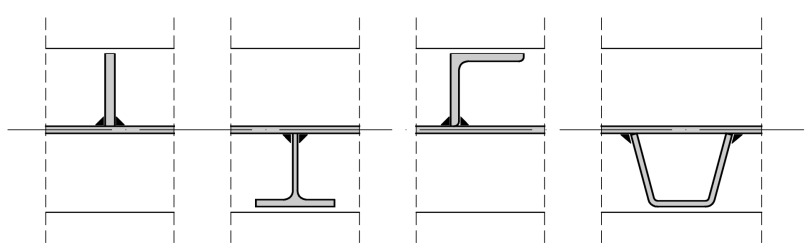

Rys. 1. Przekroje pośrednich żeber poprzecznych blachownic stalowych: a) podwójne, b) pojedyncze

Fig. 1. Steel plate girder intermediate transverse stiffener cross-sections: a) double, b) single

W przypadku użebrowanych środników o grubościach nie przekraczających $6 \mathrm{~mm}$ istotne może być zmniejszenie koncentracji naprężeń spawalniczych, które uzyskuje się stosując: żebra z płaskowników w układzie mijankowym, żebro parzyste złożone z płaskownika i połówki dwuteownika albo żebro nieparzyste z kątownika spawanego przylgowo do powierzchni środnika (rys.2).
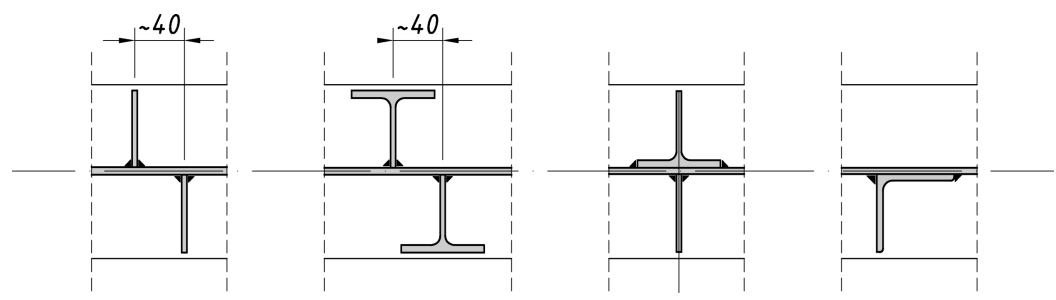

Rys. 2. Żebra usztywniające stosowane w przypadku cienkich blach środnika

Fig. 2. Stiffeners used in case of thin web plates

Najczęściej stosowanym przekrojem zastępczym żeber pośrednich jest przekrój krzyżowy. Taka forma przekroju poprzecznego charakteryzuje się zerową wartością wycinkowego momentu bezwładności, czego konsekwencją jest brak wpływu rozpiętości żebra (wysokości środnika) na wartość siły krytycznej wyboczenia skrętnego (rys. 3a). Przy stosunkowo niedużych wysokościach środników, zwiększanie pola przekroju płaskowników żeber w celu spełnienia warunku stateczności skrętnej nie ma wtedy uzasadnienia.

Racjonalnym rozwiązaniem powyższego problemu jest wykorzystanie przekrojów o niezerowej sztywności deplanacyjnej (por. rys. 3b); zwykle są to profile kątowe albo teowe, rzadziej profile zamknięte. 

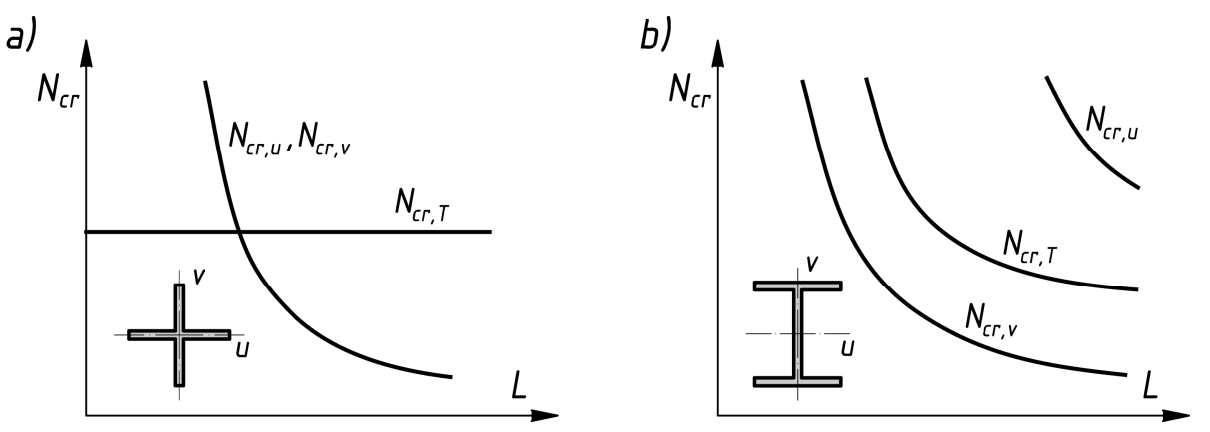

Rys. 3. Siły krytyczne wyboczenia giętnego i skrętnego w funkcji rozpiętości pręta dla profilu: a) krzyżowego i b) dwuteowego

Fig. 3. Critical forces of flexural and torsional buckling in function of a bar span for cross-section: a) cross type and b) I-shaped type

\section{Zastosowanie liniowej teorii stateczności do wyznaczania na- prężeń krytycznych płyt użebrowanych}

Głównym celem stosowania pośrednich żeber usztywniających, aż do lat 50-tych ubiegłego wieku, było zwiększenie naprężeń krytycznych smukłych płyt składowych blachownic. W szczególności chodziło o zwiększenie naprężeń krytycznych środnika poddanego działaniu naprężeń normalnych, stycznych lub ich kombinacji. Model fizyczny tego zagadnienia oparto na liniowej teorii stateczności dyskretnie użebrowanych płyt izotropowych, co implikowało przyjęcie następujących założeń upraszczających:

a) w konfiguracji początkowej płyta środnika jest idealnie płaska, a oś żebra idealnie prosta,

b) obciążenie jest przyłożone w płaszczyźnie środkowej środnika,

c) nie są uwzględnione naprężenia rezydualne,

d) w stanie wyboczenia przemieszczenia środnika są małe w porównaniu do jego grubości.

Dodatkowo zakładano, że sztywność skrętna żeber i pasów jest na tyle niewielka, że z korzyścią dla bezpieczeństwa konstrukcji można ją pominąć; stąd w praktycznych obliczeniach najczęściej przyjmowano modele płyt prostokątnych przegubowo podpartych na wszystkich krawędziach.

Zagadnienie powyższe najczęściej rozwiązywano za pomocą metody energetycznej stosując podejście Rayleigha-Ritza [por. np. 7, 23, 30]. Warunkiem osiagnięcia przez układ zachowawczy stanu równowagi krytycznej jest zerowanie się drugiej wariacji całkowitej energii potencjalnej układu П 
gdzie,

$$
\delta^{2} \Pi=0
$$

$$
\Pi=U_{p l}+U_{s t, M}+U_{s t, T}-W_{p l, \sigma}-W_{p l, \tau}-W_{s t, M}-W_{s t, T},
$$

oraz:

$U_{p l}$ - energia odkształceń sprężystych płyty,

$U_{s t, M}$ - energia odkształceń sprężystych żebra wywołana zginaniem,

$U_{s t, T}-$ energia odkształceń sprężystych żebra wywołana skręcaniem,

$W_{p l, \sigma}$ - praca sił wewnętrznych płyty wywołana naprężeniami normalnymi $\left(\sigma_{x} \mathrm{i} \sigma_{y}\right)$

$W_{p l, \tau}$ - praca sił wewnętrznych płyty wywołana naprężeniami stycznymi,

$W_{s t, N M}$ - praca sił wewnętrznych żeber powstała na skutek działania siły podłużnej i momentu zginającego,

$W_{s t, T}-$ praca sił wewnętrznych żeber powstała na skutek działania momentu skręcającego.

W zapisie równania (2) wprowadza się zmienną pomocniczą $\alpha$, charakteryzującą geometrię płyty prostokątnej

$$
\alpha=\frac{a}{b},
$$

gdzie:

$a$ - długość panelu (mierzona wzdłuż osi dźwigara),

$b$ - szerokość panelu (mierzona prostopadle do osi dźwigara).

Dodatkowo wprowadza się również trzy zmienne pomocnicze charakteryzujące żebro usztywniające:

a) względną sztywność giętną

$$
\gamma=\frac{E I_{s}}{D b}
$$

b) względną sztywność skrętną

$$
\vartheta=\frac{G I_{T}}{D b},
$$

c) względną sztywność podłużną

$$
\delta=\frac{A_{s}}{b t},
$$

gdzie:

$A_{s}$ - zastępcze pole przekroju żebra,

$E$ - współczynnik sprężystości podłużnej stali,

$I_{s}$ - moment bezwładności żebra względem płaszczyzny środnika,

$b$ - wysokość płyty środnika,

$D$ - sztywność giętna płyty środnika, 


$$
D=\frac{E t^{3}}{12\left(1-v^{2}\right)},
$$

$t$ - grubość środnika,

$v$ - współczynnik Poissona,

$G$ - współczynnik sprężystości poprzecznej stali,

$I_{T}$ - moment bezwładności skręcania swobodnego przekroju żebra otwartego

$$
I_{T}=\eta \frac{1}{3} \sum_{i=1}^{n} h_{i} t_{i}^{3}
$$

$\eta$ - współczynnik zależny od kształtu przekroju i stosunku grubości jego elementów składowych,

$n$ - liczba ścianek składowych przekroju żebra,

$h_{i}-$ długość ścianki składowej przekroju żebra,

$t_{i}$ - grubość ścianki składowej przekroju żebra.

Najczęściej równania stateczności płyt użebrowanych formułowane były przy pominięciu składników sztywności skrętnej żeber.

W opisywanej metodzie pole przemieszczeń prostopadłych do powierzchni płyty $w(x, y)$ zakładano w postaci przybliżonej, w formie podwójnego szeregu sinusowego Fouriera

$$
w(x, y)=\sum_{m=1}^{\infty} \sum_{n=1}^{\infty} a_{m n} \sin \frac{m \pi x}{a} \sin \frac{m \pi y}{b},
$$

Po podstawieniu funkcji (9) do wzoru (1) otrzymuje się równanie, w którym niewiadomymi są współczynniki szeregu $a_{m n}$ oraz bezwymiarowy parametr stateczności płyty $k$

$$
\delta^{2} \Pi=\delta^{2} \Pi\left(a_{m n}, k\right)=0 .
$$

Rozwiązanie powyższego zadania uzyskuje się wykorzystując warunek zerowania się pierwszej pochodnej drugiej wariacji całkowitej energii potencjalnej układu

$$
\frac{\partial\left(\delta^{2} \Pi\right)}{\partial a_{m n}}=0,
$$

co prowadzi do układu liniowych, jednorodnych równań algebraicznych w postaci

$$
\sum c_{i j} a_{i j}=0
$$

gdzie współczynniki $c_{i j}$ są liniowymi funkcjami parametru stateczności płyty $k$, który jest funkcją parametrów geometrii płyty i sztywności żeber: $\alpha, \gamma, \vartheta, \delta$, a ponadto spełnia równanie 


$$
k(\alpha, \gamma, \vartheta, \delta)=\frac{\sigma_{c r}}{\sigma_{E}}
$$

gdzie:

$\sigma_{c r}$ - naprężenie krytyczne analizowanej płyty,

$\sigma_{E}$ - naprężenie krytyczne Eulera - wartość pomocnicza odpowiadająca naprężeniom krytycznym jednokierunkowo ściskanego pasma płytowego o szerokości jednostkowej, podpartego przegubowo jedynie na krawędziach prostopadłych do kierunku obciążenia

$$
\sigma_{E}=\frac{\pi^{2} E}{12\left(1-v^{2}\right)}\left(\frac{t}{b}\right)^{2}
$$

Formuła (13) jest słuszna również dla krytycznych naprężeń stycznych, przy czym w tym przypadku jako parametr $b$ powinien być przyjmowany zawsze krótszy bok płyty.

Warunkiem koniecznym i wystarczającym istnienia nietrywialnego rozwiązania układu równań jednorodnych (12) jest zerowanie się wyznacznika układu

$$
\operatorname{det}\left|c_{i j}(\alpha, \gamma, \vartheta, \delta)\right|=0 \text {, }
$$

otrzymuje się stąd wielomianowe równanie charakterystyczne, którego najmniejszym pierwiastkiem jest poszukiwany parametr $k(\alpha, \gamma, \vartheta, \delta)$, pozwalający określić krytyczną wartość naprężeń płyty użebrowanej.

Opisana powyżej metoda jest metodą przybliżoną, której dokładność zależy od liczby wyrazów szeregu aproksymującego pole przemieszczeń $w(x, y)$. Ze względu na żmudność obliczeń rachunkowych metoda ta stała się użyteczna w projektowaniu dźwigarów blachownicowych dopiero po wprowadzeniu komputerów do praktyki obliczeniowej, co w krajach zachodnich miało miejsce pod koniec lat 50-tych ubiegłego wieku, a w Polsce około dziesięć lat później.

\section{Zagadnienie sztywności optymalnej żebra poprzecznego}

Ekonomiczne kształtowanie użebrowanych płyt środników wymaga racjonalnego doboru rozstawu żeber oraz wyznaczenia ich minimalnej sztywności giętnej, przy której naprężenie krytyczne płyty środnika byłoby maksymalne. Sformułowanie problemu optymalizacji jest jednak utrudnione, ponieważ w zależności od parametrów geometrycznych płyty, warunków obciążenia i rodzaju użebrowania, wzrost sztywności giętnej żebra skutkuje różnym zachowaniem się płyty użebrowanej w kontekście osiaganych naprężeń krytycznych, co pokazano na rys. 4 i 5 sporządzonych na podstawie pracy [25]. W literaturze przedmiotu zdefiniowane zostały trzy rodzaje sztywności optymalnej żebra [7, 25]. 


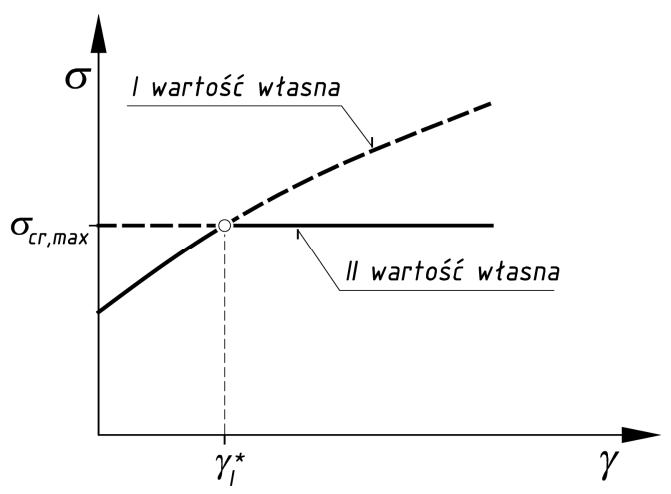

Rys.4. Sztywność optymalna pierwszego rodzaju $\gamma_{I}{ }^{*}$

Fig. 4. Optimal stiffness of the first kind $\gamma_{I}^{*}$

Sztywność optymalna pierwszego rodzaju $\gamma_{I}^{*}$ (rys. 4) - minimalna względna sztywność giętna żebra, przy której naprężenie krytyczne płyty użebrowanej osiąga wartość maksymalną; dalszy wzrost sztywności żebra nie powoduje wzrostu naprężeń krytycznych, a linia węzłowa wyboczonej powierzchni pokrywa się z osią żebra. Przy sztywnościach żebra mniejszych od $\gamma_{I}{ }^{*}$ możliwa jest tylko jedna forma utraty stateczności sprężystej, przy której żebro odkształca się wraz z płytą. Sztywność tego rodzaju nie zawsze jest możliwa do określenia - zależy to od położenia żebra i rodzaju obciążenia płyty.

Sztywność optymalna drugiego rodzaju $\gamma_{I I}$ (rys. 5) - względna sztywność giętna żebra, przy której naprężenia krytyczne odpowiadające dwóm różnym postaciom wyboczenia są sobie równe; nie otrzymuje się przy tym maksymalnych naprężeń krytycznych, a oś żebra nie pozostaje prosta. Przy sztywnościach żebra mniejszych od $\gamma_{I I}$ możliwe są dwie formy utraty stateczności sprężystej. W obydwu przypadkach linia węzłowa nie pokrywa się z osią żebra, zatem w stanie wyboczenia płyty żebro ulega zginaniu. Maksymalne naprężenia krytyczne są osiagane przy sztywności żebra zmierzającej do nieskończoności, lecz po przekroczeniu wartości $\gamma_{I I} *$ dalszy wzrost naprężeń krytycznych płyty jest stosunkowo niewielki, a zwiększanie sztywności żebra staje się ekonomicznie nieuzasadnione.

Sztywność optymalna trzeciego rodzaju $\gamma_{I I}$ * - względna sztywność giętna żebra, przy której naprężenia krytyczne całej płyty są równe naprężeniom krytycznym panelu najbardziej niekorzystnie obciążonego, dla którego przyjmuje się schemat płyty przegubowo podpartej na wszystkich czterech krawędziach. Wymusza to przyjęcie koncepcji tzw. ,żebra sztywnego”. Jeżeli dla danej płyty użebrowanej istnieje sztywność optymalna pierwszego rodzaju to jest ona równa sztywności optymalnej trzeciego rodzaju. Trzecia koncepcja sztywności optymalnej jest najbardziej uniwersalna, może być stosowana niezależnie od rodzaju użebrowania i obciążenia płyty. Podkreślić należy jednak to, 
że sztywność $\gamma_{I I I}$ * nie zapewnia osiągnięcia maksymalnych możliwych naprężeń krytycznych, ani uformowania się linii węzłowych wyboczonej powierzchni płyty w osiach żeber, jednak ze względu na to, że projektowanie upraszcza się do projektowania pojedynczych paneli środnika jest ona często stosowana w literaturze i określana krótszym terminem sztywności optymalnej $\gamma^{*}$.

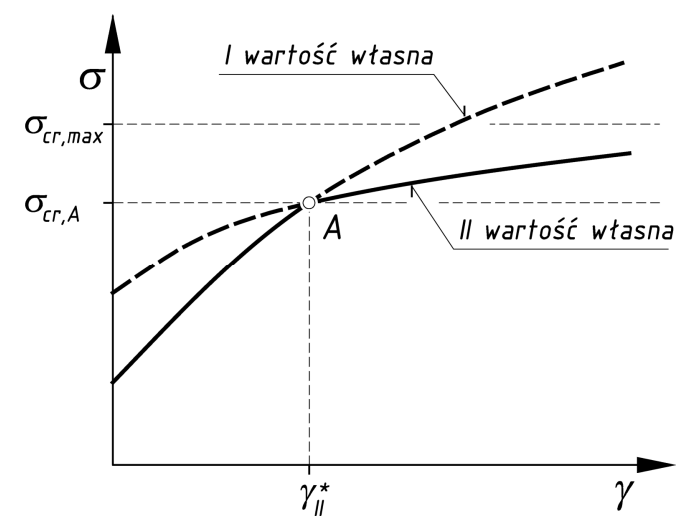

Rys. 5. Sztywność optymalna drugiego rodzaju $\gamma_{I I}{ }^{*}$

Fig. 5. Optimal stiffness of the second kind $\gamma_{I I}{ }^{*}$

W klasycznym sformułowaniu sztywność optymalna żebra poprzecznego jest funkcją rodzaju obciążenia oraz stosunku długości krawędzi płyty $\alpha$. $\mathrm{Z}$ punktu widzenia praktyki projektowej bezpieczne oszacowanie przekroju żebra jest możliwe na podstawie sztywności optymalnej $\gamma^{*}(\alpha)$ żebra płyty obciążonej naprężeniami stycznymi, co pokazano na rys. 6 [7]. Uniwersalność takiego podejścia może jednak być okupiona przewymiarowaniem poprzecznych żeber usztywniających. Na podstawie analizy charakterystyk przedstawionych na rys. 3 można również zauważyć, że zależność $\gamma^{*}(\alpha)$ jest nieliniową funkcją monotonicznie malejąca, przy czym dla $\alpha<\sim 1,0$ jest ona silnie malejąca, natomiast dla $\alpha>\sim 1,0$ spadek wartości $\gamma^{*}$ jest stosunkowo niewielki i w tym przedziale funkcja $\gamma^{*}(\alpha)$ mogłaby być aproksymowana funkcją stała.

Pierwsze analityczne rozwiązanie problemu sztywności optymalnej użebrowania płyty ścinanej przedstawił Timoshenko (1915) [27], podając w sposób stabelaryzowany wartości $\gamma^{*}$ dla płyt prostokątnych przegubowo zamocowanych w pasach i usztywnionych jednym albo dwoma żebrami poprzecznymi (patrz tab. 2). 


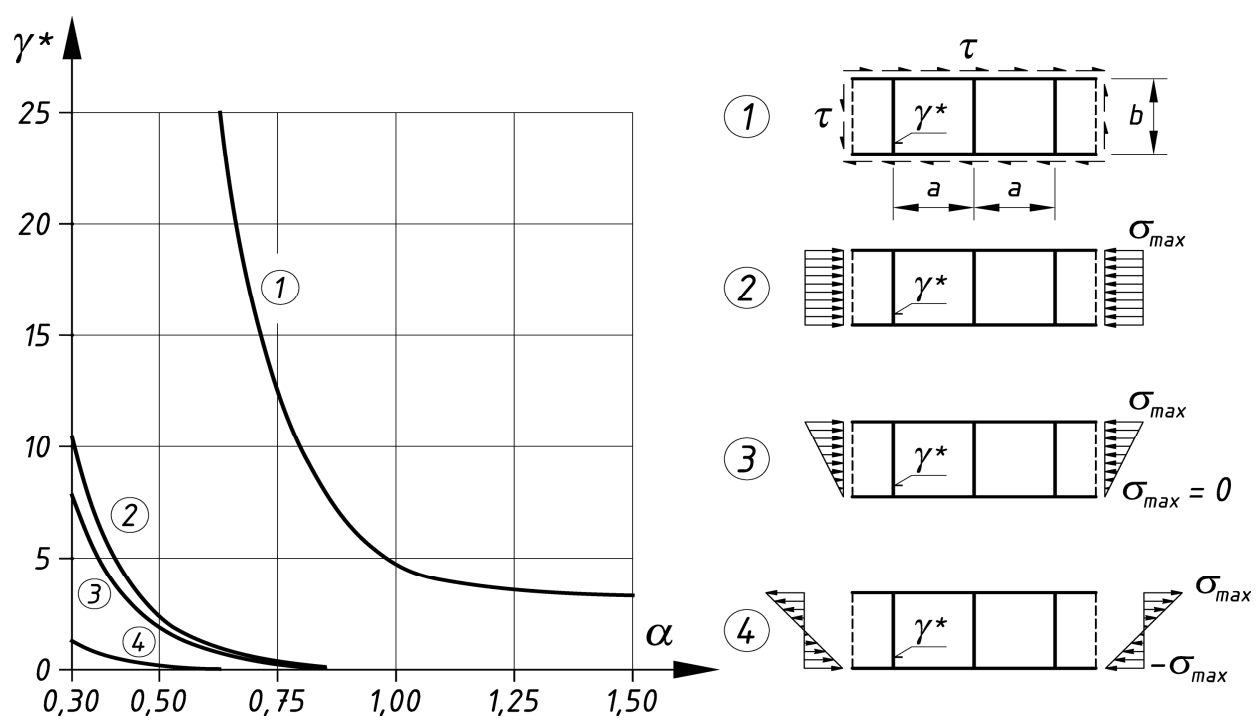

Rys.6. Porównanie optymalnej względnej sztywności giętnej żebra dla różnych przypadków obciążeniowych według M. Mele

Fig. 6. Comparison of optimal relative flexural stiffness of a stiffener for different load cases according to M. Mele

Tabela 2. Wartości względnych sztywności optymalnych żeber poprzecznych $\gamma^{*}$ na podstawie[27]

Table 2. Transversal stiffeners relative flexural stiffness $\gamma^{*}$ values according to [27]

\begin{tabular}{|c|c|c|c|c|c|c|c|}
\hline \multirow{2}{*}{$\begin{array}{c}\text { Liczba } \\
\text { żeber }\end{array}$} & \multicolumn{7}{|c|}{ Parametr geometrii płyty $\alpha[-]$} \\
\cline { 2 - 8 } & 3,0 & 2,5 & 2,0 & 1,5 & 1,25 & 1,2 & 1,0 \\
\hline 1 & - & - & 0,83 & 2,9 & 6,3 & - & 15 \\
\hline 2 & 0,64 & 1,37 & 3,53 & 10,7 & - & 22,6 & - \\
\hline
\end{tabular}

Pierwsze formuły otrzymane na drodze eksperymentalnej były również uzależnione od stosunku długości krawędzi płyty $\alpha$. Uniwersalna, niezależna od rodzaju obciążenia formuła empiryczna podana przez Moore’a (1942) [17] stanowi aby sztywność żebra nie była mniejsza niż

$$
\gamma^{*}=\frac{14}{\alpha^{3}} .
$$

Wraz z początkiem lat 50-tych ubiegłego wieku nastąił intensywny przyrost liczby prac dotyczących stateczności płyt użebrowanych. W okresie tym pojawiło się również wiele opracowań dotyczących problemu wyznaczania sztywności optymalnej podłużnych, poprzecznych i przekątnych (ukośnych) żeber blachownic. Rozważano najczęściej płyty prostokątne o różnej konfiguracji geometryczno-obciążeniowej, które usztywnione były jednym lub wieloma 
żebrami równoległymi do krawędzi płyty wariantując przy tym rodzaj utwierdzenia płyt na ich krawędziach podparcia. Spośród licznych opracowań wymienić należy tutaj m.in.: doświadczalno-teoretyczną pracę Steina i Fralicha [26], publikację Wanga dotyczącą stateczności płyty o nieskończonej długości [29], opracowanie Seidego dotyczące stateczności żebra jednostronnego [24], pracę doktorską Bornscheuera w której uwzględniono sztywność skrętnej żeber [3] oraz pracę habilitacyjną Kowala [13], w której przedstawiono rozwiązania analityczne problemów stateczności liniowej i nieliniowej płyt środników użebrowanych poprzecznie i przekątnie oraz wyznaczono sztywność optymalną żebra przekątnego. Szeroki przegląd klasycznych, analitycznych metod wyznaczania sztywności żeber zawiera m.in. monografia Bulsona (1970) [5]. Znaczny wkład we wdrożenie do praktyki projektowej obliczeń stateczności płyt użebrowanych i sztywności optymalnej żeber mają dwie słynne monografie: Klöppela i Scheera [11] oraz Klöppela i Möllera [12], które oprócz szczegółowego opisu matematycznego rozwiązania problemu zawierały wiele praktycznych formuł, wykresów oraz zapisów w formie macierzowej, które w istotny sposób ułatwiały komputerowe prowadzenie obliczeń. Przykładowo, dla środnika usztywnionego jedynie żebrami poprzecznymi, poddanego działaniu naprężeń stycznych optymalna sztywność względna według Klöppela i Scheera [11] wynosi

$$
\gamma^{*}=\frac{5,4}{\alpha}\left(\frac{2}{\alpha}+\frac{2,5}{\alpha^{2}}-\frac{1}{\alpha^{3}}-1\right) \text { przy czym } 0,5 \leq \alpha \leq 2,0
$$

Rozwiązania czysto teoretyczne były poddawane weryfikacji eksperymentalnej. W 1956 r. Rockey [22] na podstawie przeprowadzonych 220 badań doświadczalnych zaproponował dwie formuły na sztywność względną żebra współosiowego i mimośrodowego względem płaszczyzny środnika

$$
\gamma^{*}=\left\{\begin{array}{cc}
\frac{28}{\alpha}-20 \alpha & \text { dla żeber wspáosiowych } \\
\frac{21,5}{\alpha^{2}}-7,5 & \text { dla żeber mimosrodowych }
\end{array},\right.
$$

Massonnet i Greisch (1955) [15] zaproponowali nieciagłą funkcję sztywności optymalnej żebra $\gamma^{*}(\alpha)$ w postaci

$$
\gamma^{*}=\left\{\begin{array}{lrc}
\frac{28}{\alpha}-20 \alpha & \text { dla } & 0,2<\alpha<1,0 \\
8 & \text { dla } & \alpha \geq 1,0
\end{array} .\right.
$$

Na podstawie sztywności optymalnej $\gamma^{*}$ wyznaczonej według zasad liniowej teorii stateczności nie mogą być wymiarowane żebra blachownic w stanie nadkrytycznym oraz żebra poprzeczne, które stanowią podparcie dla więcej niż dwóch żeber podłużnych. 


\section{Rozwiązania oparte na nieliniowej teorii stateczności płyt}

Zastosowanie liniowej teorii stateczności płyt użebrowanych wymagało przyjęcia nierealistycznych założeń o idealnie płaskiej powierzchni płyty środnika i prostoliniowej osi żebra. Proces wytwarzania blachownicy stalowej jest zawsze źródłem nieuniknionych imperfekcji geometrycznych (wygięcia osi żeber oraz wybrzuszenia wstepne i mimośrody scalenia płyt składowych) oraz strukturalnych (naprężenia własne: walcownicze, spawalnicze, montażowe). Konfiguracja z imperfekcjami początkowymi skutkuje powstaniem stanu odkształceń giętnych w płycie środnika już na początku procesu obciążania blachownicy. Odkształcenia te narastają wraz ze wzrostem obciążenia, zatem przy osiągnięciu wartości krytycznej obciążenia nie występuje gwałtowne przejście z bezgiętnego stanu tarczowej pracy środnika do giętnego stanu powyboczeniowego, co podważa celowość analizy stateczności w ujęciu bifurkacyjnym. Zgodnie z normą PN-EN 1090-2 [19] dopuszczalne wybrzuszenie środnika wynosi $\pm 1 / 100$ i $\pm 1 / 150$ wysokości środnika, odpowiednio dla 1. i 2. klasy wykonania konstrukcji. Blachownica nie obciążona może zatem mieć deformacje większe od grubości jej środnika, nie jest więc możliwe utrzymanie założenia o małych przemieszczeniach, ani w stanie podkrytycznym, ani tym bardziej w stanie nadkrytycznym. Uwzględnienie postulatu dużych przemieszczeń wymaga zastosowania nieliniowej teorii stateczności płyt. Prace $\mathrm{z}$ tego zakresu są stosunkowo nieliczne, zagadnieniom tym pod koniec lat 60-tych ubiegłego wieku poświecili swoje prace m.in. Massonnet [16] i Škaloud [25].

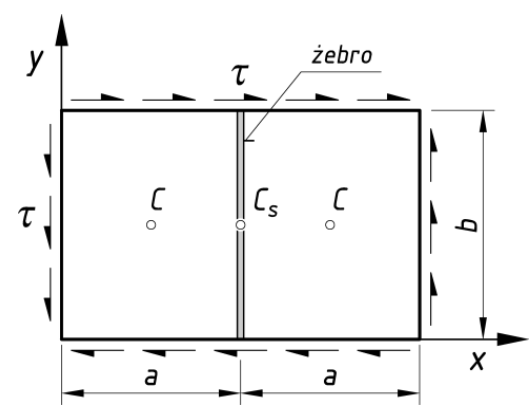

Rys. 7. Płyta prostokątna usztywniona pojedynczym żebrem analizowana przez Škalouda

Fig. 7. The single stiffener reinforced rectangular plate analyzed by Škaloud

Rozwiązanie zagadnienia stateczności nieliniowej płyty prostokątnej o wymiarach jak na rys. 7 [25], usztywnionej żebrem poprzecznym w połowie szerokości, obciążonej naprężeniami stycznymi na obwodzie i podpartej przegubowo, nawet w przypadku przyjęcia braku początkowych imperfekcji geometrycznych oraz naprężeń rezydualnych, wymaga wyznaczenia rozwiązania układu dwóch równań różniczkowych cząstkowych, równania nierozdzielności (20) i równania równowagi (21) z zadanymi kinematycznymi i statycznymi warunkami brzegowymi, 


$$
\begin{gathered}
\frac{\partial^{4} \Phi}{\partial x^{4}}+2 \frac{\partial^{4} \Phi}{\partial x^{2} y^{2}}+\frac{\partial^{4} \Phi}{\partial x^{4}}=E\left[\left(\frac{\partial^{2} w}{\partial x \partial y}\right)-\frac{\partial^{2} w}{\partial x^{2}} \frac{\partial^{2} w}{\partial y^{2}}\right] \\
\frac{D}{t}\left(\frac{\partial^{4} w}{\partial x^{4}}+2 \frac{\partial^{4} w}{\partial x^{2} y^{2}}+\frac{\partial^{4} w}{\partial y^{4}}\right)=\frac{\partial^{2} \Phi}{\partial y^{2}} \frac{\partial^{2} w}{\partial x^{2}}+\frac{\partial^{2} \Phi}{\partial x^{2}} \frac{\partial^{2} w}{\partial y^{2}}-\frac{\partial^{2} \Phi}{\partial x \partial y} \frac{\partial^{2} w}{\partial x \partial y}
\end{gathered}
$$

Rozwiązanie powyższego zagadnienia brzegowego metodami analitycznymi napotyka poważne trudności obliczeniowe. Stosując podejście Papkowicza, Škaloud [25] otrzymał rozwiązanie analityczne równania nierozdzielności (20) oraz, przy zastosowaniu metody energetycznej, rozwiązanie przybliżone równania równowagi (21). Ze względu na wymaganą dokładność rozwiązania, funkcja przemieszczeń $\mathrm{w}$ stanie powyboczeniowym została przyjęta $\mathrm{w}$ postaci pierwszych sześciu wyrazów podwójnego szeregu sinusowego, co skomplikowało obliczenia na tyle, że niemożliwe było uzyskanie rozwiązania w postaci funkcji jawnej. Wartości poszukiwanej funkcji przemieszczeń $w(x, y)$ obliczono $\mathrm{w}$ arbitralnie wybranych punktach analizowanej płyty, co umożliwiło zbadanie wpływu względnej sztywności giętnej żebra $\gamma / \gamma^{*}$ oraz względnego naprężenia krytycznego $\tau / \tau_{c r} *$ na przemieszczenia żebra (patrz rys. 8 według [25]), przy czym wielkości oznaczone symbolem * odpowiadają sztywności optymalnej i naprężeniom krytycznym tej samej płyty otrzymanym przy zastosowaniu liniowej teorii stateczności płyt użebrowanych. Wykazano, że w stanie nadkrytycznym sztywność żebra będzie wystarczająca jeśli przyjąć wartość sztywności $\gamma^{*}$ przemnożoną przez współczynnik zwiększający $m_{S}$ o wartości 3,0,

$$
\gamma_{o}=m_{S} \gamma^{*}
$$

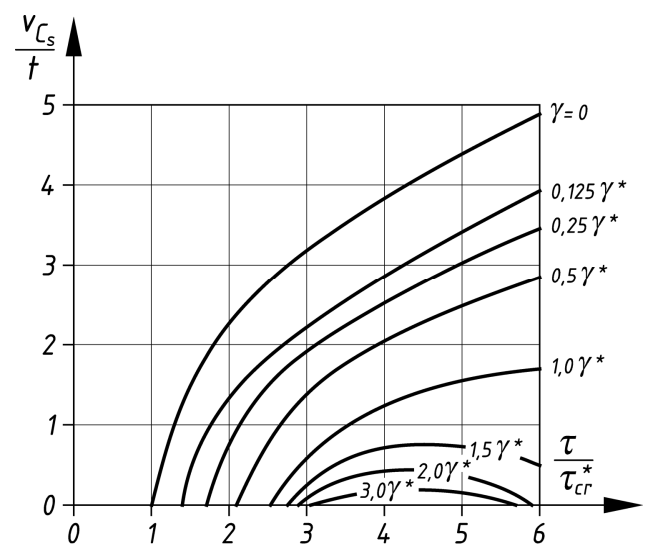

Rys. 8. Przemieszczenia względne punktu $C_{s}$ w funkcji względnych naprężeń stycznych płyty analizowanej przez Škalouda

Fig. 8. Relative displacement of $C_{s}$ point in function of relative shear stresses in the plate analyzed by Škaloud 
Porównując rozwiązania Škalouda i Massonneta z wynikami badań doświadczalnych Maquoi [14] zaproponował następujący sposób wyznaczania optymalnej sztywności żeber dla środników blachownic pracujących w stanach nadkrytycznych,

gdzie,

$$
\gamma_{o}=m_{M} \gamma^{*}
$$

$$
m_{M}=\left\{\begin{array}{ccc}
1,0 & \text { dla } & b / t \leq 75 \\
3,0 & \text { dla } & b / t \geq 150
\end{array},\right.
$$

oraz $\gamma^{*}$ - sztywność optymalna żebra wyznaczona wg teorii stateczności liniowej płyt użebrowanych.

\section{Sztywność żeber poprzecznych w nadkrytycznym stanie no- śności blachownicy}

Przejście blachownicy do stanu nadkrytycznego wywołuje jakościowe i ilościowe zmiany dystrybucji sił wewnętrznych w płytach składowych. Często stosowanym modelem obliczeniowym blachownicy w stanie nadkrytycznym jest kratownica Pratta, w której słupki stanowią żebra poprzeczne, a strefy pól ciagnień w środniku formują krzyżulce. Stosowanie takiego modelu wymaga wymiarowania żebra poprzecznego nie tylko ze względu na opisywany wcześniej warunek sztywności, lecz również sprawdzenia warunku nośności żebra traktowanego jak pręt ściskany osiowo. Powyższe podejście do wymiarowania żeber poprzecznych jest stosowane $\mathrm{w}$ większości współczesnych norm projektowania konstrukcji stalowych - również w normach polskich [18] i [20].

Oryginalną metodę wymiarowania żeber pośrednich blachownic w stanach nadkrytycznych, polegającą na weryfikacji przekroju żebra jedynie ze względu na warunek sztywności, przedstawili Ballio i Mazzolani (1983) [2]. Uznali oni, że warunek sztywności giętnej żebra należy uzupełnić dodatkowym warunkiem sztywności podłużnej

gdzie:

$$
A_{s} \geq \delta^{*} b t
$$

$A_{\mathrm{s}}$ - zastępcze pole przekroju żebra składające się z kształtowników przylegających do środnika oraz przyległej części płyty środnika o szerokości $5 t$ z każdej strony żebra,

$\delta^{*}$ - optymalna względna sztywność podłużna żebra,

$$
\delta^{*}=\left(1-\frac{\sigma_{c r, r e d}}{f_{y}}\right) \rho \phi\left(\frac{c}{a}\right)_{\min }
$$


w którym: $\sigma_{c r, \text { red }}$ - naprężenie krytyczne płyty środnika w złożonym stanie naprężeń, zredukowane ze względu na nieliniowość charakterystyki materiałowej $\sigma-\varepsilon$ poniżej granicy plastyczności,

$$
\sigma_{c r, \text { red }}=f_{y} \frac{20+\sqrt{25-15\left(\frac{f_{y}}{\sigma_{c r, i d}}\right)^{2}}}{25+\left(\frac{f_{y}}{\sigma_{c r, i d}}\right)^{2}},
$$

$\sigma_{c r, i d}$ - naprężenia krytyczne płyty w złożonym stanie obciążeń, wyznaczone według klasycznej teorii stateczności liniowej,

$\rho$ - współczynnik korekcyjny,

$$
\rho=\frac{2 \alpha}{1+\alpha^{2}} \eta
$$

przy czym,

$$
\eta=\left\{\begin{array}{ccc}
1,6-\alpha & \text { dla } & 0,2 \leq \alpha \leq 0,6 \\
1 & \text { dla } & \alpha>0,6
\end{array},\right.
$$

$\phi$ - współczynnik bezwymiarowy zależny od kształtu i mimośrodowości żebra (tabl. 3)

Tablica 3. Współczynniki kształtu i mimośrodowości żebra $\phi$ na podstawie [2]

Table 3. Stiffener shape and eccentricity coefficient $\phi$ according to [2]

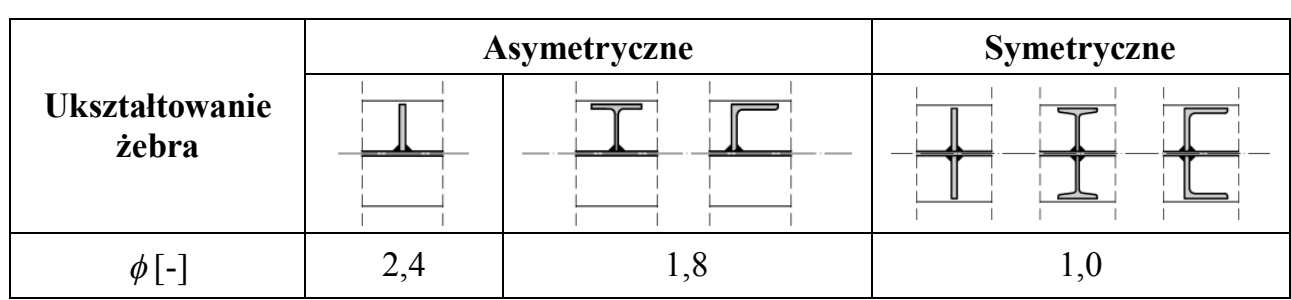

$\left(\frac{c}{a}\right)_{\min }$ - minimalny względny rozstaw przegubów plastycznych w pasach w stanie granicznym nośności blachownicy

$$
\left(\frac{c}{a}\right)_{\min }=\frac{v_{c} \tau_{m}-\frac{\sigma_{c r, r e d}}{\sqrt{3}}}{\frac{2 \alpha}{1+\alpha^{2}}\left(f_{y}-\sigma_{c r, r e d}\right)},
$$


gdzie: $v_{\mathrm{c}}$ - częściowy współczynnik bezpieczeństwa ujmujący błąd metody (nie wyspecyfikowany przez autorów metody),

$\tau_{m}$ - uśrednione naprężenie styczne w przekroju blachownicy wyznaczonym przez oś żebra,

Metoda obliczeniowa zaproponowana przez Ballio i Mazzolaniego nie znalazła zastosowania $\mathrm{w}$ wytycznych normowych. Jednak podobne podejście do wymiarowania pośrednich żeber poprzecznych zawarto w wytycznych AASHTO (1996) [1].

\section{Warunek sztywności pośrednich żeber poprzecznych w nor- mach i wytycznych projektowania}

Wymiarowanie pośrednich żeber poprzecznych blachownic przewidzianych do pracy w stanie podkrytycznym przez wiele dziesięcioleci przeprowadzano stosując formuły wyprowadzone na podstawie liniowej teorii stateczności płyt użebrowanych. W ujęciu normowym często, zamiast względnej sztywności giętnej żebra, posługiwano się bezwzględną sztywnością giętną żebra $I_{s}$, którą można zapisać przekształcając wzór (4),

$$
I_{s}=0,092 \gamma_{n}^{*} b t^{3}=k_{s} b t^{3},
$$

gdzie $\gamma^{*}{ }_{n}$ - normowa względna sztywność giętna żebra oraz $k_{s}$ - bezwymiarowy współczynnik sztywności żebra.

Zgodnie z zaleceniami normy PN-B 03200:1990 [18] sztywność żebra poprzecznego nie powinna być mniejsza niż

$$
I_{s}=k_{s} b t^{3}=\frac{1,5}{\alpha^{2}} b t^{3} \quad \text { przy czym } k_{s} \geq 0,75
$$

Podobne zalecenie zawiera prenorma europejska ENV 1993-1-1:1992[9] oraz współczesna norma PN-EN 1993-1-5 [20]

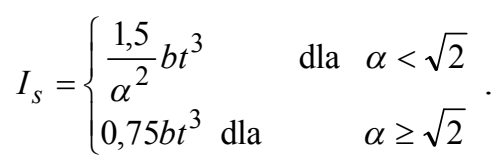

W polskiej normie mostowej PN-S 10052:1989 [21] zawarto bardziej restrykcyjne ograniczenie sztywności minimalnej żeber konstrukcyjnych

$$
I_{s}=3 b t^{3} .
$$

Sztywność pośredniego żebra poprzecznego według wytycznych ECCS (1978) [8] oraz AASHTO (1996) [1] powinna spełniać warunek 
gdzie,

$$
I_{s} \geq \xi \cdot I^{*},
$$

$$
I^{*}=\left(2,5\left(\frac{1}{\alpha}\right)^{2}-2\right) a t^{3}, \text { lecz } I^{*} \geq \frac{a t^{3}}{2}
$$

przy czym $\xi=4,0$ dla otwartych przekrojów żeber,

$\xi=2,5$ dla zamkniętych przekrojów żeber.

Zgodnie z wytycznymi AASHTO [1] żebra poprzeczne blachownic w stanie nadkrytycznym powinny dodatkowo spełniać warunek sztywności podłużnej określający minimalne pole przekroju poprzecznego żebra $A_{s}$

$$
A_{s} \geq\left(0,15 \phi b t\left(1-\frac{\tau_{c r} \sqrt{3}}{f_{y}}\right) \frac{V_{E d}}{V_{u}}-18 t^{2}\right) \frac{f_{y}}{\sigma_{c r, l o c a l}},
$$

gdzie:

$\phi$ - parametr zależny od kształtu i mimośrodowości żebra, przyjmowany według tabl. 3,

$\tau_{c r}$ - sprężyste styczne naprężenia krytyczne panelu środnika,

$V_{E d}$ - obliczeniowa wartość siły poprzecznej w przekroju wyznaczonym przez oś żebra,

$V_{u}$ - obliczeniowa nośność graniczna panelu środnika,

$\sigma_{c r, \text { local }}$ - minimalne sprężyste naprężenia krytyczne odpowiadające utracie stateczności lokalnej ścianek przekroju żebra.

Analizując przedstawione na rys. 9 wykresy współczynników sztywności giętnej $k_{s}$ żeber pośrednich wybranych formuł teoretycznych i empirycznych oraz zaleceń normowych, można zauważyć, że prawie wszystkie charakterystyki mają ten sam typ zmienności - stanowią monotonicznie malejące funkcje parametru geometrii płyty $\alpha$, analogicznie do krzywej optymalnej względnej sztywności giętnej panelu ścinanego przedstawionej na rys. 6. Wyjątek stanowi charakterystyka współczynnika $k_{s}$ wyznaczonego według normy [21] - stosunkowo konserwatywnie określająca sztywność żebra oraz charakterystyka według propozycji Klöppela i Scheera (16). 


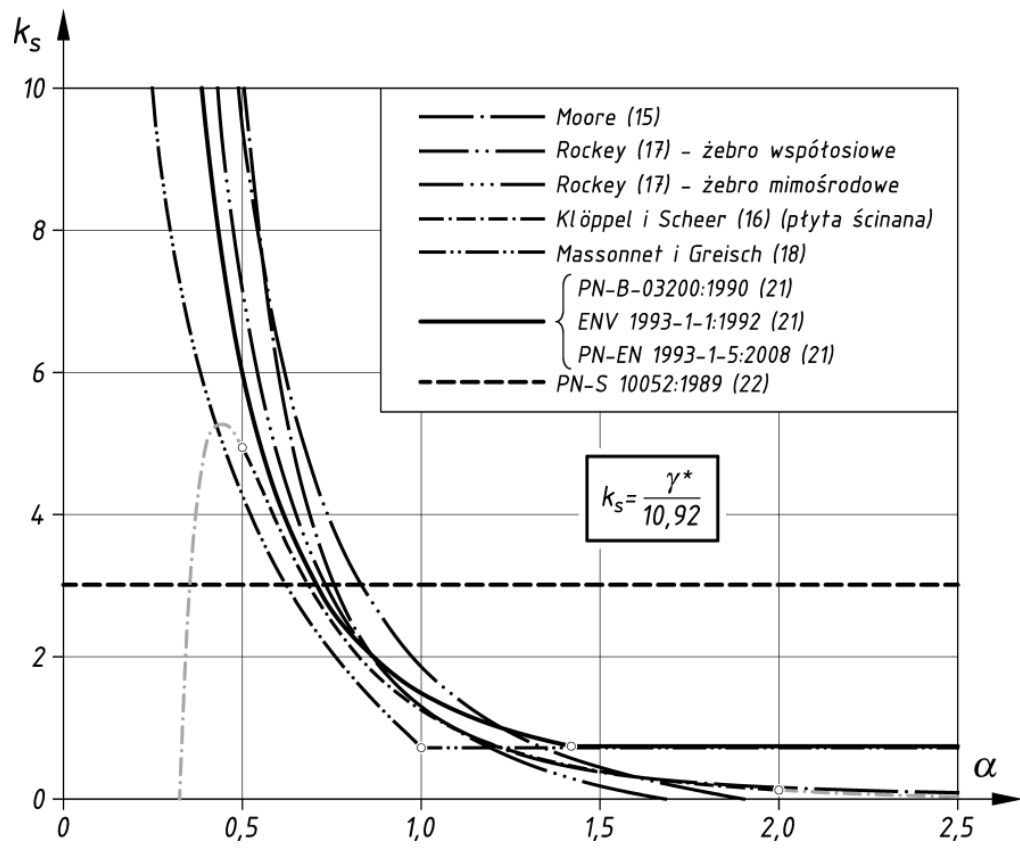

Rys. 9. Porównanie współczynników sztywności giętnej żeber poprzecznych $k_{s}$

Fig. 9. Comparison of transversal stiffener bending stiffness coefficients $k_{s}$

Stałą wartość współczynnika $k_{s}$ dla paneli środnika wydłużonych w kierunku osi blachownicy przyjmuje się dla $\alpha>\sqrt{ } 2$, zgodnie z propozycjami normowymi $[9,18,20]$. Podobną zależność wprowadzili Massonnet i Greisch [15] dla $\alpha>1,0$. Wraz z wydłużaniem się panelu środnika maleje wpływ żebra na zwiększanie się naprężeń krytycznych. Przyjęcie stałej wartości współczynnika $k_{s}$ dla paneli wydłużonych wynika z badań doświadczalnych i ma na celu zabezpieczenie rzadko użebrowanych blachownic przed dystorsyjnymi deformacjami przekroju poprzecznego oraz zredukowanie oddziaływań wynikających $\mathrm{z}$ działania naprężeń normalnych $\mathrm{w}$ środniku na mimośrodach wywołanych wstępnymi wybrzuszeniami środnika.

\section{Podsumowanie}

Kryterium sztywności giętnej jest podstawowym warunkiem projektowym dla poprzecznego żebra usztywniającego blachownicę zarówno $\mathrm{w}$ stanie podkrytycznym jak i nadkrytycznym. Wyznaczenie optymalnej sztywności giętnej żebra jest zagadnieniem złożonym, w którym zmienność parametrów wejściowych powoduje nie tylko ilościowe lecz również jakościowe zróżnicowanie odpowiedzi modelu obliczeniowego. 
Wymiarowanie żeber poprzecznych blachownic wyłącznie na podstawie kryterium sztywności giętnej jest możliwe jedynie w podkrytycznym stanie wytężenia blachownicy. W stanie nadkrytycznym, ze względu na uformowanie się w środniku pól ciągnień, żebro zaczyna przenosić obciążenia podłużne pełniąc funkcję słupków kratownicy Pratta w zastępczym schemacie statycznym blachownicy. Wytworzenie się takiego mechanizmu pracy blachownicy w stanie nadkrytycznym jest możliwe przy spełnieniu warunku sztywności giętnej żebra, natomiast uzyskanie znaczącego wzrostu nośności poprzez wykorzystanie rezerwy nadkrytycznej jest możliwe przy spełnieniu dodatkowych warunków. Najczęściej są to warunki nośności żebra jako elementu ściskanego osiowo siłami wynikającymi z działania pól ciagnień uzupełnione dodatkowymi wymaganiami pozwalającymi zabezpieczyć żebro przed wystąpieniem przestrzennych form niestateczności, tj. utraty stateczności lokalnej i stateczności skrętnej. W nielicznych opracowaniach $[1,2]$ dodatkowe warunki wymiarujące żebro w stanie granicznym nośności są formułowane na podstawie kryterium sztywności podłużnej.

Zgodnie ze współczesnym trendem w projektowaniu lekkich konstrukcji stalowych, stanowiących przede wszystkim elementy nośne hal o lekkim pokryciu ścian i dachu, preferowane są blachownice bezżebrowe, jako mniej pracochłonne w wykonaniu. Faworyzowanie rozwiązań tego typu wynika z aktualnego stanu wyposażenia wytwórni konstrukcji stalowych w linie technologiczne do automatycznego spawania blach środników z pasami. Obecnie wprowadzane są już do użytkowania pierwsze, w pełni zrobotyzowanie, linie technologiczne scalania i spawania kształtowników budowlanych, które umożliwiają produkcję elementów w skali niskoseryjnej a nawet jednostkowej. Można zatem przypuszczać, że na przestrzeni kilku lat opisany powyżej trend może ulec zmianie.

\section{Literatura}

[1] AASHTO: Standard specifications for highway bridges. American Association of State Highway \&Transportation Officials, Washington, D.C., 1996.

[2] Ballio G., Mazzolani F. M.: Theory and Design of Steel Structures, Chapman and Hall, London-New York, 1983.

[3] Bornscheuer F. W.: Beitrag zur Berechnung ebener, gleichmäßig gedrückter Rechteckplatten, versteift durch eine Längssteife, Dissertation, TH Darmstadt, 1946, cyt. za: [27].

[4] BS 5400-3: Steel, concrete and composite bridges. Code of practice for design of steel bridges, BSI, London, 2000.

[5] Bulson P. S.: The Stability of Flat Plates, Chatto \& Windus, London, 1970.

[6] DASt - Richtlinie 015: Träger mit schlanken Stegen, Deutscher Ausschuß für Stahlbau, Stahlbau-Verlagsgesellschaft, Köln, 1990. 
[7] Dubas P., Gehri E.: Behaviour and Design of Steel Plated Structures, ECCS-CECMEKS, Brussels, 1986.

[8] ECCS: European Recommendation for Steel Construction, European Convention for Constructional Steelwork, Brussels, 1978.

[9] ENV - 1993-1-1, Design of Steel Structures - Part 1.1 General rules and rules for buildings, European Prenorm, CEN, Brussels, 1992.

[10] Galambos T. V.: Guide to Stability Design Criteria for Metal, 4th Edition, John Wiley \& Sons, New York, 1988.

[11] Klöppel K., Scheer J.: Beulwerte ausgesteifter Rechteckplatten, Verlag von Wilhelm Ernst \& Sohn, Berlin, 1960.

[12] Klöppel K., Möller K. H.: Beulwerte ausgesteifter Rechteckplatten, II Band, Verlag von Wilhelm Ernst \& Sohn, Berlin, 1968.

[13] Kowal Z.: Dźwigary blachowe z użebrowaniem pionowym i przekątnym, Zeszyty Naukowe Politechniki Wrocławskiej nr 97, Wrocław, 1964.

[14] Maqoui R., Massonnet Ch., Škaloud M.: Design of Stiffened Webs, Stavebnícky časopis, No. 2, 1981, s.73-88, cyt. za: [25].

[15] Massonnet Ch., Greisch R.: Dimensionnement pratique des raidisseurs des poutres à ame pleine en tenant compte du danger de voilement, Note technique C-10.1, Centre de Recherches Scientifiques et Techniques de l'Industrie des Fabrications Métalliques, Bruxelles, 1955, cyt. za: [7]

[16] Massonnet Ch., Škaloud M., Donéa J.: Comportement postcritique d'une plaque carrée raidie cisaillée uniformément. Deuxiéme partie: Repartition des contraintes et analyse de l'état limite. Mémoires de l'AIPC, Vol. 28, 1968, s.137-156, cyt. za [25].

[17] Moore R. L.: An Investigation on the Effectiveness of Stiffeners on Shear Resistance Plate Girder Webs, Technical Note No. 921, National Advisory Committee for Aeronautics, Washington, 1942.

[18] PN-90/B-03200: Konstrukcje Stalowe. Obliczenia statyczne i projektowanie, Wydawnictwa Normalizacyjne Alfa-Wero Sp. z o.o., Warszawa, 1995.

[19] PN-EN 1090-2:2008: Wykonanie konstrukcji stalowych i aluminiowych. Część 2. Wymagania dotyczące konstrukcji stalowych.

[20] PN-EN 1993-1-5: Eurokod 3. Projektowanie konstrukcji stalowych. Część 1-5: Blachownice, PKN, Warszawa, 2008.

[21] PN-S-10052:1982: Obiekty mostowe. Konstrukcje stalowe. Projektowanie. PKNMiJ, Warszawa, 1982.

[22] Rockey K.C.: The Design of Intermadiate Vertical Stiffeners on Web Plates Subjected to Shear, Aeronautical Quarterly, Vol. 7, s. 275-296.

[23] Rykaluk K.: Zagadnienia stateczności konstrukcji metalowych, Dolnośląskie Wydawnictwo Edukacyjne, Wrocław, 2012.

[24] Seide P.: The Effect of Longitudinal Stiffeners Located on One Side of a Plate on the Compressive Buckling Stress of the Plate-Stiffener Combination, Technical Note No. 2873, National Advisory Committee for Aeronautics, Washington, 1953. 
[25] Škaloud M.: Optimum Rigidity of Stiffeners of Web and Flanges; w Narayanan R. (editor): Plated Structures. Stability and Strenght, Applied Science Publishers Ltd., London-New York, 1983.

[26] Stein M., Fralich R. W.: Critical Shear Stress of Infinitely Long Simply Supported Plate with Transverse Stiffeners, Technical Note No. 1851, National Advisory Committee for Aeronautics, Washington, 1949.

[27] Timoshenko S. P., Gere J. M.: Teoria stateczności sprężystej, Arkady, Warszawa, 1963.

[28] Timoshenko S. P.: Historia wytrzymałości materiałów, Arkady, Warszawa, 1966.

[29] Wang T. K.: Buckling of Transverse Stiffened Plates under Shear, Journal of Applied Mechanics, Vol. 14, No.4, 1947, s. A269-A274, cyt. za: Naleszkiewicz J.: Zagadnienia stateczności sprężystej, Wydawnictwa Komunikacyjne, Warszawa, 1953.

[30] Вольмир А. С.: Устойчивость деформируемых систем, Издательство “Наука", Москва, 1967.

\title{
STIFFNESS CRITERION IN INTERMEDIATE TRANSVERSAL STIFFENER DESIGN
}

\begin{abstract}
S u m m a r y
In the paper basic methods of plate girder intermediate transversal stiffeners design according to bending and extensional stiffness criterions were presented. Scope of this paper covers a description of conceptions and methods of optimal relative bending stiffness of plate girders intermediate transversal stiffeners determining based on linear and nonlinear stiffened plate stability theory. Proposals of plate girder transversal stiffeners design in post-critical range was presented. In this range design of transversal stiffeners is additionally based on stiffeners extensional stiffness criterion. Stiffeners bending stiffness requirements according to selected steel structures design codes and theoretical and empirical formulae was compared.
\end{abstract}

Keywords: grillage of stiffeners, transversal stiffeners, intermediate stiffeners, Eurocode 3, plates stability

Przestano do redakcji:15.09.2014

Przyjęto do druku:1.12.2015

DOI: $10.7862 / \mathrm{rb} .2015 .152$ 